\title{
A GEOTERMIKUS ENERGIA HELYZETE VILÁGSZERTE ${ }^{1}$
}

\section{THE GLOBAL POSITION OF GEOTHERMAL ENERGY}

\author{
Rybach László Ladislaus \\ mérnök, professor emeritus, Institut für Geophysik ETHZ, Zürich, Svájc \\ rybach@ig.erdw.ethz.ch
}

\begin{abstract}
ÖSSZEFOGLALÁS
A cikk a sekély és mély geotermikus készletekből globálisan előálított elektromos árammal és a közvetlenül felhasznált hővel kapcsolatos adatokat közli. Az áramadatok összehasonlítása során az évi növekedési tendenciák azt mutatják, hogy a geotermia a napelemes és szélgenerátoros áramfejlesztéshez képest alaposan lemarad. A magyar geotermikus potenciál elismerten magas, de a fejlődési mutatók jelenleg egyenlőtlenek. Viszont a Pannon-medence első geotermikus erőműve nemrég Magyarországon indult be. Erről is találhatók számadatok a cikkben.
\end{abstract}

\section{ABSTRACT}

The paper discusses the data related to globally produced electric energy from shallow and deep geothermal supplies and directly used heat. When comparing relevant data, the annual increase of usage of geothermal energy lags behind that of the usage of energies produced by solar plants and wind generators. Hungary has great geothermal potential but the parameters showing the development are uneven. Nevertheless, the very first geothermal power plant in the Pannonian Basin started production recently in Hungary. Related numerical data are also published in this paper.

Kulcsszavak: áramfejlesztés, geotermikus energia, közvetlen hőhasznosítás, éves növekedés, befektetési különbségek, magyarországi tendenciák

Keywords: electricity generation, geothermal energy, direct heat use, annual growth rates, investment differences, Hungarian development trends

\section{BEVEZETÉS}

A magyar kormány 2008-ban megrendelt egy stratégiai tanulmányt a Magyar Tudományos Akadémiától a hazai geotermikus energia hasznosításának előkészítésére. A tanulmány kidolgozására az MTA az Eötvös Loránd Tudományegye-

\footnotetext{
${ }^{1}$ Az előadás itt közölt, szerkesztett változata Szabados László szaklektor közremüködésével készült.
} 
temet (ELTE) kérte fel, ahol erre egy munkacsoport alakult, Mádlné Szőnyi Judit vezetésével. Ennek tagja lett e közlemény szerzője is, és ez a közremüködés a tanulmányban $A$ földhö felhasználásának nemzetközi helyzete címü fejezetét eredményezte.

Az ELTE munkacsoportjának tanulmányát összefoglalóan ismerteti Mádlné Szőnyi Judit és szerzőtársai cikke (2009). A cikk a földhőhasznosítás fő kategóriáit (geotermikus áramfejlesztés, közvetlen hőhasznosítás) külön-külön tárgyalja, az elért eredményeket és a jövőbeni lehetőségeket is.

Azóta több országban, különféle alkalmakkor hangzottak el hasonló témájú előadások a szerzőtől, amelyek aztán kiterjedtek a többi megújuló energia (biomassza, vízi erő, napelemek, szélenergia) nemzetközi helyzetére is.

Az alábbiak a geotermikus energia hasznosítása terén elért eredményeket, a jelenlegi fejlődési tendenciákat, valamint a jövőbeli esélyeket ismertetik.

\section{ADATGYŰJTÉS, FELDOLGOZÁS, ANALÍZIS}

Az elért eredmények, megmutatkozó fejlődési jelenségek és jövőbeli lehetőségek szemléltetésére leginkább alkalmas nemzetközi számadatok a geotermiában csak ötévenként állnak rendelkezésre: a World Geothermal Congress (WGC) alkalmával nyilvánosságra kerülő számadatok formájában. Így rendelkezésre állnak a geotermikus áramfejlesztés és a közvetlen hőhasznosítás jellemző adatai (áramfejlesztés: beépített kapacitás $\mathrm{MW}_{\mathrm{e}}$-ben, évi megtermelt árammennyiség GWhban; hőhasznosítás: beépített kapacitás $\mathrm{MW}_{\text {th}}$-ban, höátadás GJ-ban).

Az évi adatok összehasonlítása, azok időbeni ábrázolása tisztán mutatja a fejlödési tendenciákat, valamint a növekedési indikátorokat (például: lineáris vagy exponenciális fejlődés; növekedés százalékban). Ezek alapján időnként helyzetjelentést lehet tenni. Ez történt például a HUNGEO 2014-es konferencián a WGC 2010 statisztikai adatai alapján kidolgozott eredmények és tendenciák közzétételével. Ebből egy hosszabb cikk keletkezett (Rybach, 2015), amely részletesen közli az alkalmazott munkamódszert; emiatt itt csak a legfrissebb eredményeket mutatom be. Ezek a REN21 Global Status Reportban (2017), valamint a WGC 2015-ön közölt számadatokon alapulnak.

\section{KÖZVETLEN HŐHASZNOSIITÁS}

A felhasznált adatok forrása John W. Lund és Tonya L. Boyd (2015) tanulmánya; a számok a 2014. év végi helyzetet mutatják. A globális geotermikus hőhasznosítás 2014-ben 590 PJ (petajoule) volt 82 országban, $70 \mathrm{GW}_{\text {th }}$ teljesítménnyel. A globális hőhasználat egyenletesen növekszik, kb. évi 12\%-kal. Ennek több mint 
felét a geotermikus hőszivattyúrendszerek szolgáltatták. Az utóbbi technológia, amely sekély ( $<400$ méter mélységü) készleteken alapul, jelenleg a legsikeresebb. Ezt a beépített kapacitás időben exponenciális növekedése bizonyítja (1. ábra). Európában különösen sikeresek a földhőszivattyús rendszerek, leginkább Svédországban. A 2. ábra a beépített teljesítményt ábrázolja országonként. Magyarország nincs az első húsz ország között (Rybach-Sanner, 2017).

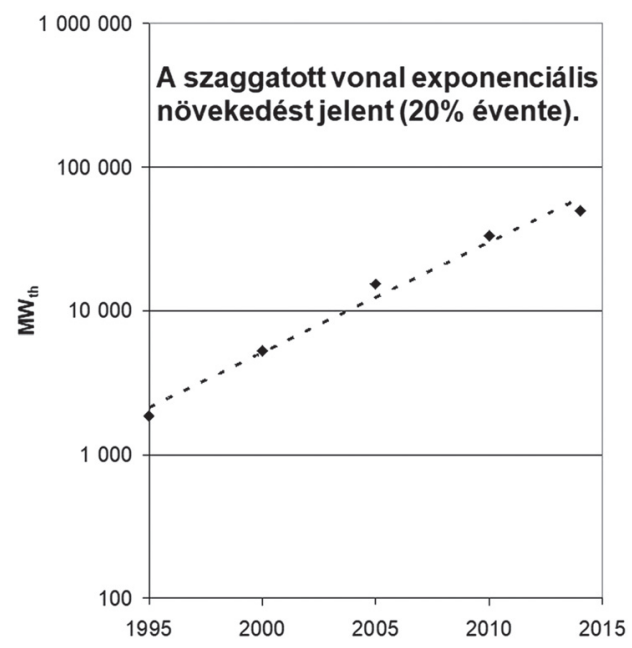

1. ábra. A geotermikus hőszivattyúk (geothermal heat pumps, GHP - sekély geotermia) fejlődése húsz év folyamán. A globális évi 20\%-os exponenciális növekedés jelentős

(Lund-Boyd, 2015 adatai alapján saját szerkesztés)

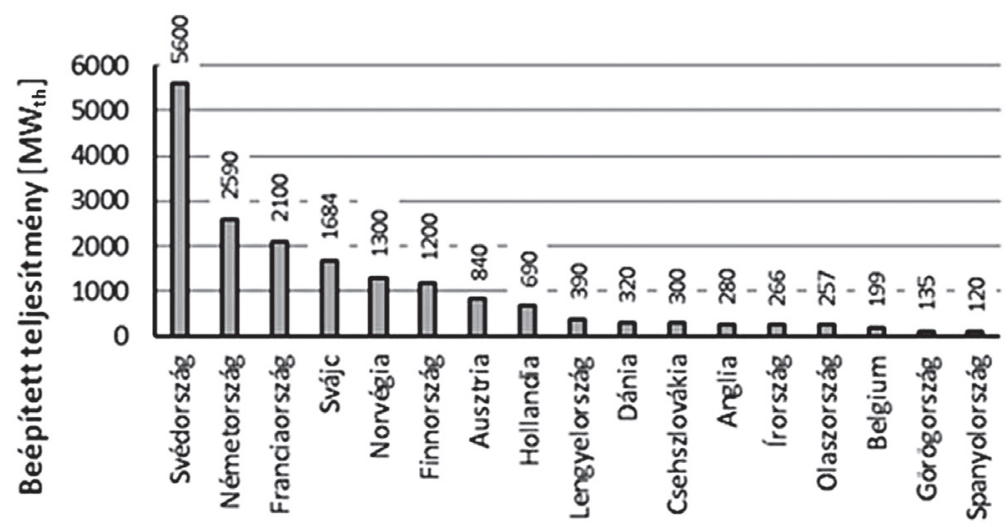

2. ábra. Beépített GHP-teljesítmény különböző európai országokban

(Rybach-Sanner, 2017 alapján saját szerkesztés) 
A földhőszivattyúk mellett több más geotermikus technológiát is alkalmaznak. Mindezek mély (> 400 méter) készletekre alapulnak. Az 1. táblázat országonként sorban mutatja ezeket: távfütés, mezőgazdasági alkalmazások, hévízfürdőzés, egyéb használat. Ebben a mezőnyben Magyarország az elökelö negyedik helyen szerepel.

1. táblázat. A különféle közvetlen geotermikus hőhasznosítások beépített teljesítménye $\left(\mathrm{MW}_{\mathrm{th}}\right)$, mély (> 400 m) készletekből, az élenjáró tíz európai országban (ETIP, 2018).

További 16 más európai országban is van kisebb hasznosítás

\begin{tabular}{|l|c|c|c|c|c|}
\hline \multicolumn{1}{|c|}{ Ország } & Távfütés & $\begin{array}{c}\text { Mezógazdaság, } \\
\text { haltenyésztés }\end{array}$ & Hévízfürdés & $\begin{array}{c}\text { Egyedi } \\
\text { épületfütés } \\
\text { és egyebek }\end{array}$ & Összesen \\
\hline Törökország & 1032 & 794 & 1016 & 413 & 3255 \\
\hline Izland & 1873 & 57 & 64 & 111 & 2105 \\
\hline Olaszország & 127 & 222 & 428 & 603 & 1380 \\
Magyarország & 127 & 318 & 254 & 29 & 728 \\
\hline Franciaország & 450 & 30 & 20 & - & 500 \\
\hline Németország & 270 & - & 45 & 3 & 318 \\
\hline Románia & 159 & 7 & 9 & - & 175 \\
\hline Szlovákia & 14 & 28 & 86 & 20 & 148 \\
\hline Hollandia & - & 118 & - & - & 118 \\
\hline Szerbia & 45 & 15 & 38 & 12 & 110 \\
\hline
\end{tabular}

\section{GEOTERMIKUS ÁRAMFEJLESZTÉS}

A másik nagy geotermikus kategória, az áramfejlesztés adatai több forrásból származnak: Bertani (2015), GEA (2014), ThinkGeoEnergy (2017), REN21 (2017). A 2. táblázat a 2014. év végi helyzetet ábrázolja (Bertani, 2015); akkor Dél-Amerika kivételével a világ összes kontinensén volt geotermikus erömü. Manapság van már Chilében is. A legújabb adatokat a ThinkGeoEnergy (2017) közli; eszerint 2017 végén a világszerte huszonhat országban müködő geotermikus erőmüvek összteljesítménye elérte a $14 \mathrm{GW}_{\mathrm{e}}$ kapacitást. Ugyanezen forrás szerint ez a teljesítmény ugyanebben az évben összesen kb. 80 TWh geotermikus áramot produkált, ami megfelel a globális áramfejlesztés 0,3\%-ának. 
2. táblázat. Geotermikus erőművek eloszlása világszerte és az országonként beépített teljesítmények $\left(\mathrm{MW}_{\mathrm{e}}\right)$. Az adatok a 2014. év végi helyzetet mutatják. Azóta van fejlődés, 2017 végén a globális összteljesítmény elérte a $14 \mathrm{GW}_{\mathrm{e}}$ értéket (ThinkGeoEnergy, 2017).

Az erőművek voltaképpen mind hidrotermális készletekből termelnek

(Bertani, 2015 alapján)

\begin{tabular}{|c|c|c|c|c|c|c|c|c|c|c|c|}
\hline \multicolumn{2}{|c|}{$\begin{array}{c}\text { Észak- } \\
\text { Amerika }\end{array}$} & \multicolumn{2}{|c|}{ Közép-Amerika } & \multicolumn{2}{|c|}{ Afrika } & \multicolumn{2}{|c|}{ Európa } & \multicolumn{2}{|c|}{ Ázsia } & \multicolumn{2}{|c|}{ Óceánia } \\
\hline USA & 3450 & Mexikó & 1017 & Kenya & 594 & Olaszo. & 916 & $\begin{array}{l}\text { Fülöp- } \\
\text { szigetek }\end{array}$ & 1870 & Új-Zéland & 5 \\
\hline & & Costa Rica & 207 & Etiópia & 7 & Izland & 665 & Indonézia & 1340 & $\begin{array}{l}\text { Pápua- } \\
\text { Új-Guinea }\end{array}$ & 50 \\
\hline & & Salvador & 204 & & & Portugália & 29 & Japán & 519 & Ausztrália & 1 \\
\hline & & Nicaragua & 159 & & & Németo. & 27 & Töröko. & 397 & & \\
\hline & & Guatemala & 52 & & & Franciao. & 16 & Oroszo. & 82 & & \\
\hline & & & & & & Ausztria & 1 & Kína & 27 & & \\
\hline
\end{tabular}

A továbbiakban a globális geotermikus áramfejlesztés időbeni fejlődését vizsgáljuk. A 3. ábra azt mutatja, hogy a geotermikus áramszolgáltatás folyamatosan és közel lineárisan növekszik. De milyen tempóban? Ha megvizsgáljuk a 2011-2017-es időszakot (a növekvési görbe legmeredekebb szakaszát), akkor évi

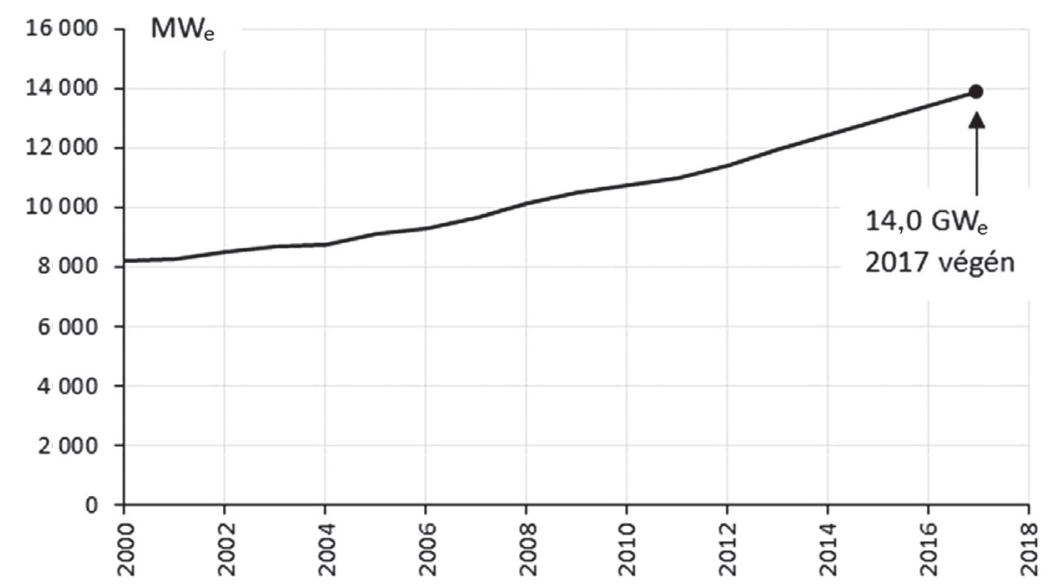

3. ábra. A világszerte beépített geotermikus erőművek teljesítménynövekedése az idő függvényében, a GEA (2014) szerint, kiegészítve a 2017 végére jelentett értékkel

(ThinkGeoEnergy, 2017). 2011 és 2017 között a növekedés elérte a 4,6\%-ot

(saját szerkesztés) 
4,6\% növekedés tapasztalható. De ez egy globális átlag. Vannak viszont kiugró elörelépések is, ebben Törökország élenjáró: amíg beépített teljesítményük Ruggero Bertani (2015) statisztikája szerint csupán $397 \mathrm{MW}_{\mathrm{e}}$ volt, az EGEC 2018 Geothermal Market Report (EGEC, 2019) már $1315 \mathrm{MW}_{\mathrm{e}}$-t jelez!

A következőkben a geotermikus áramtermelés fejleményeit hasonlítjuk össze más megújuló energiák, a biomassza, a vízenergia, a napenergia (napelemek) és a szélerőalapú erőmüvek növekedési és egyéb számmutatóival.

\section{GEOTERMIA ÉS NAPENERGIA}

A nagy hatású REN21-hálózat évente részletes jelentést állít össze a megújuló energiák globális fejlődéséről. A továbbiakban a REN21 Global Status Report 2017 publikációban szerepló adatok alapján szerzett tapasztalatokat ismertetem.

A REN21 (2017) 66. oldalán látható diagramból kiderül, hogy a globális napelemes áramfejlesztés rohamosan növekszik. Kiszámítható, hogy a beépített kapacitás 2006 óta exponenciálisan, évi 40\%-kal nő. A 4. ábra összehasonlítja ezt a fejlődést a geotermikus áramfejlesztés görbéjével (3. ábra). Ugyanis a REN21 ábrába be van építve a globális geotermikus összteljesítmény adatpontja 2017-ben, valamint a geotermikus áramfejlesztés, szaggatott vonallal. A különbség óriási. Ebben a gigawattos léptékben alig észlelhető, hogy 2007-ig a geotermikus áramfejlesztés kapacitása még jóval megelőzte a napelemes értékeket.

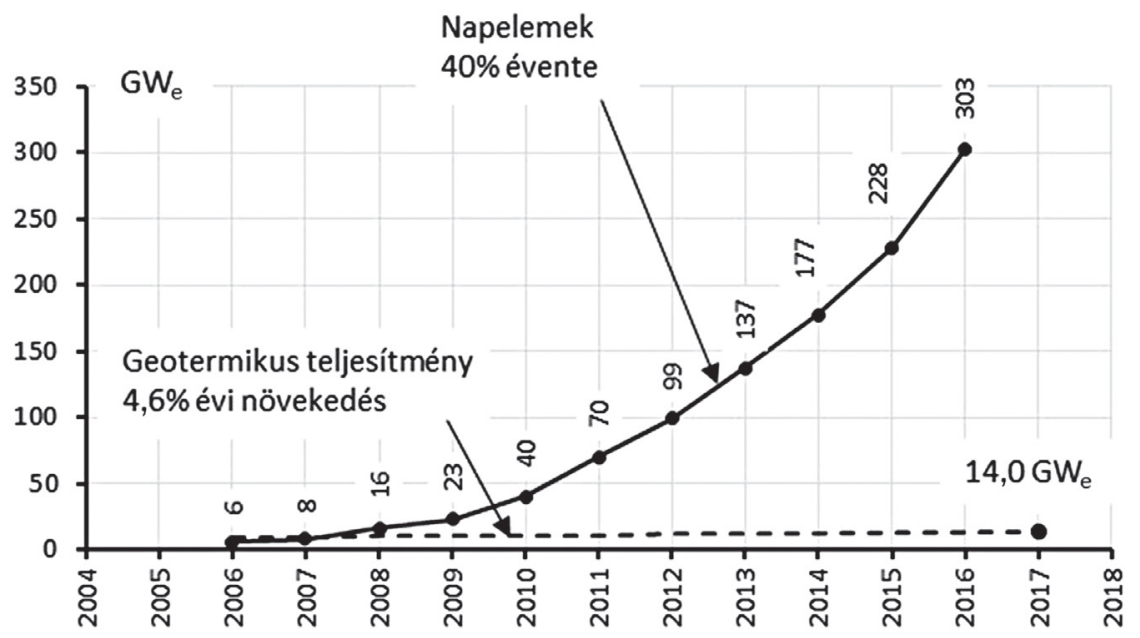

4. ábra. A globális napelemes áramfejlesztés növekedése a 2006-2017 közötti időszakban (REN21, 2017; ThinkGeoEnergy, 2017), a geotermikus áramfejlesztés növekedésével összehasonlítva. A geotermia alaposan lemarad

(saját szerkesztés) 


\section{HATÉKONYSÁGI ÖSSZEHASONLLITÁS}

Míg a geotermia alapja, a földhő éjjel-nappal, télen-nyáron rendelkezésre áll, addig a nap nem süt, és a szél nem fúj mindig. Számszerủleg mit jelent ez a különbség? Ennek eldöntéséhez szükség van a beépített kapacitások mellett az egy évben termelt árammennyiségekre is. Ezek alapján összehasonlítható a különböző áramfejlesztési technológiák hatásfoka. Ez az összeállitás a nap- és geotermikus energiákon kívül más megújuló energiákra alapuló technológiákra (vízerő, biomassza, szélerö) is kiterjed. A 3. táblázat az idetartozó eredményeket közli, szintén a REN21 Global Status Report 2017 számértékei alapján.

Ebben az összehasonlításban külön szerepel a technológiák hatékonysága. A müködés hatásfoka az évi termelés és a beépített kapacitás alapján számítható.

3. táblázat. Megújuló áramfejlesztési technológiák globális termelési jellemzői.

Külön kiemelendő az utolsó oszlop (hatékonyság): egy év (összesen 8760 óra) mekkora részében (\%) termel egy adott technológia, a REN21 (2017)

kapacitás- és termelésadatai alapján számolva

\begin{tabular}{|c|c|c|c|c|c|}
\hline \multirow{2}{*}{ Technológia } & \multicolumn{2}{|c|}{ Beépített kapacitás } & \multicolumn{2}{|c|}{ Áramtermelés } & A múködés hatásfoka \\
\hline & $\mathbf{G W}_{\mathrm{e}}$ & $\%$ & TWh/év & $\%$ & $\%$ \\
\hline Vízerő & 1096,0 & 54,5 & 4902 & 72,6 & 51,0 \\
\hline Biomassza & 112,0 & 5,5 & 504 & 7,5 & 51,4 \\
\hline Szélerő & 487,0 & 24,2 & 895 & 13,3 & 21,0 \\
\hline Geotermia & 13,5 & 0,7 & 76 & 1,1 & 64,3 \\
\hline Napelemek & 303,0 & 15,1 & 371 & 5,5 & 14,0 \\
\hline Összesen 2016-ban & & 100,0 & 6748 & & \\
\hline
\end{tabular}

A táblázatból kitünik, hogy a geotermia a legkisebb számokkal szerepel a hatékonyság kivételével. Itt megjegyzendö, hogy a geotermia sem teljesít 100\%-osan (nem mindig termelnek az erőmüvek teljes kapacitással, karbantartási leállások, termelés szünetei stb.). A REN21 korábbi jelentései mutatják, hogy a globális napelemes áramtermelés csak 2011-ben előzte meg a geotermikus áramét. 


\section{A VILÁGPIACI HELYZET}

Geotermikus áramszolgáltatás. Az előbbiekből is látszik a szél- és napenergia (főleg a napelemek) előretörése az áramfejlesztésben, vagyis a geotermia fejlödése alaposan lemarad a nap- és szélenergia sikereitől. Pontosabban a napelemek teljesítménye évi 40\%-kal nő, a szélerőmüveké 17\%-kal (szintén a REN21 [2017] adatai alapján), viszont a geotermikus áramé csak 4,6\%-kal.

Hogyan viszonyul mindez a többi megújuló technológiához? Szintén a REN21 (2017) ad közre ilyen jellegű számadatokat, mégpedig a létrejött befektetéseket (4. táblázat). Itt sokmilliárdos USD befektetésekről van szó; a nap- és szélenergia befektetési mutatói többszörösen felülmúlnak minden más, a megújuló energiákon alapuló áramfajtát. Ez tény, és ez az előny aligha lesz behozható.

4. táblázat. A 2016-ban különböző megújuló energiákon alapuló elektromos technológiákba világszerte befektetett US dollármilliárdok

(REN21, 2017 alapján)

\begin{tabular}{|l|c|c|c|}
\hline \multicolumn{1}{|c|}{ Energiafajta } & Fejlett országok & Fejlődő országok & Ebböl Kína \\
\hline Napenergia & 56,2 & 57,5 & 39,9 \\
Szélenergia & 60,6 & 51,9 & 35,0 \\
Biomassza & 5,2 & 1,6 & 0,9 \\
Kis méretű vízi erő & 0,2 & 3,4 & 0,5 \\
Geotermia & 0,8 & 2,0 & 0,2 \\
Tengeri hullámzás & 0,2 & 0,01 & 0,007 \\
\hline
\end{tabular}

Direkt geotermikus höhasználat. Egyöntetü globális fejlődés itt alig jelentkezik, a növekedés országonként erősen változik. Például az egyik országban sikeres földhőszivattyús technológia fejlesztése megindulhat egy szomszédos országban is, viszont más szomszédok még várnak, pedig a sekély készletekben alig lehet különbség. Itt még sok ismeretterjesztési feladat vár a szakemberekre.

Mély, magasabb hőmérsékletü készletek nagyobb mértékủ feltárása és sikeres kihasználása, például távfütésre, erősen függ a helyi geológiai adottságoktól. Hidrotermális készletek, természetes termálvíztartalmú tárolókkal aránylag ritkán fordulnak elö; a költséges kutató mélyfúrások nem mindig sikeresek. Sajnos éppen a geotermikus fejlesztések első fázisában legmagasabb a befektetési igény, valamint annak a kockázatossága is. 
Összevetve: a geotermikus hőhasználat az utóbbi években globálisan kb. évi 12\%-kal növekszik, ami jórészt a földhőszivattyús rendszerek sikerének köszönhetö. Még egy összehasonlítás: a napkollektoros vízmelegítés világszerte legalább évi 27\%-kal növekszik.

\section{VÁRHATÓ GLOBÁLIS FEJLŐDÉSI TENDENCIÁK A GEOTERMIÁBAN}

Rövid és középtávon a tradicionális geotermikus technológiák (földhöszivattyúzás, távfütés, áramfejlesztés) további fejlődése várható. Mivel mindezek majdnem kizárólag hidrotermális készletekből termelnek, viszont ilyen készletek világszerte csak aránylag ritkán fordulnak elö, az eddigi növekedési tempó aligha lesz gyorsítható. Jelenleg kezd elterjedni a kaszkádos fluidhőhasználat, lépcsőzetesen csökkenő hőmérsékletekkel: geotermikus erőmü $\rightarrow$ épületfütés $\rightarrow$ üvegházak $\rightarrow$ haltenyésztés.

Közép- és hosszú távon kívánatos, hogy végre sikerüljön az igazi geotermikus potenciál feltárása: a több kilométer mélységü, $100{ }^{\circ} \mathrm{C}$-nál melegebb kőzetek elvileg mindenütt jelen lévő magas hőtartalmának (petrotermális készlet) felszínre hozatala, ún. EGS-rendszerekkel (Enhanced/Engineered Geothermal System).

Az EGS-nél először a kőzetek áteresztőképességét kell megnövelni hidraulikus repesztéssel mélyfúrások által, így hőcserélővé tenni a repesztett kőzetfelületeket, s végül besajtoló- és termelőfúrásokkal mesterséges cirkulációt létrehozni. Ez irányú kutatás és fejlesztés már több országban folyik. Különös figyelmet kíván a szeizmikus kockázat meghatározása és csökkentése, ugyanis a hidraulikus repesztés földrengéseket okozhat. A sikeres EGS-technológia egyszer még igazi fordulópontot jelenthet!

\section{ÉS MAGYARORSZÁGON?}

Magyarország a Pannon-medencében fekszik; ennek megfelelően különösen nagy a geotermikus potenciálja. Ez az itt vékony litoszférának és az ennek megfelelően magas földi hőáramnak, valamint a medence üledékeiben elhelyezkedő gazdag hidrotermális készleteknek köszönhetö (Bobok-Tóth, 2010; Horváth et al., 2015).

Ennek a potenciálnak hasznosítására már temérdek termálkutat fúrtak. Horváth Ferenc és szerzőtársai (2015) adatai alapján kiszámítható, hogy Magyarországon átlagosan 10 kilométerenként található egy termálkút. Geotermikus kutak ilyen nagy sürüsége más országban nincs!

A magyar geotermia fejlődésének mutatói elég egyenetlen képet tárnak elénk: a hivatalos statisztikai adatok (a World Geothermal Congressek során közreadott 
számok alapján) nem egységesek. Ezzel kapcsolatban az 5. táblázatban három mutató és azok változása szerepel: az országszerte beépített direkt hőhasználati teljesítmény $\left(\mathrm{MW}_{\mathrm{th}}\right)$, a termelt hőmennyiség (TJ/év), valamint ezek ötévenkénti változása $(\%)$.

A direkt hőhasználat Tóth Anikó (2010, 2015) és Árpási Miklós (2005) által közölt számai a következő kategóriákból származnak: egyedi épületfütés, távfütés, melegházak, haltenyésztés, állattenyésztés, mezőgazdasági szárítás, ipari szárítás, balneológia/úszás, hőszivattyúzás. A közölt höszivattyús adatok (beépített kapacitás) elég változatosak: 2005-ben 4, 2010-ben 40, 2015-ben $42 \mathrm{MW}_{\text {th. }}$.

5. táblázat. A Magyarországon direkt geotermikus hőhasználatra beépített összteljesítmény, az ezzel évente termelt hömennyiség, valamint ezek változása öt év alatt (az ötévenként megtartott World Geothermal Congresseken bemutatott számadatokkal)

\begin{tabular}{|l|c|c|c|c|}
\hline Adatforrás & $\begin{array}{c}\text { Beépített teljesítmény } \\
\mathrm{MW}_{\mathrm{t}}\end{array}$ & $\begin{array}{c}\text { Változás } \\
\%\end{array}$ & $\begin{array}{c}\text { Termelt hőmennyiség } \\
\text { TJ/év }\end{array}$ & $\begin{array}{c}\text { Változás } \\
\%\end{array}$ \\
\hline Tóth (2015) & 905,58 & & 10268,06 & \\
\hline Tóth (2010) & 654,6 & +38 & & +5 \\
\hline Árpási (2005) & 694,2 & -6 & 9767,00 & +23 \\
\hline
\end{tabular}

Úgy látszik, Magyarország az első egy, a Pannon-medencében telepített geotermikus erőmủ realizálásában: a ThinkGeoEnergy 2017. november 17-én jelentette: „First geothermal heat and power plant of Hungary connected to grid”. A Turawell erőmü Tura város mellett, Budapesttől $50 \mathrm{~km}$-re keletre található; a jelentés szerint $7 \mathrm{MW}_{\text {th }}$, illetve $3 \mathrm{MW}_{\mathrm{e}}$ teljesítménnyel müködik. Remélhetőleg hamarosan több más erőművet is létesítenek a Pannon-medencében.

\section{ÖSSZEFOGLALÁS, KITEKINTÉS}

A geotermia előnyei sokfélék: igen jelentős, de még csak kezdetileg kiaknázott potenciálja van, időben állandóan szolgáltat, elvileg mindenütt elöfordul, környezetbarát, sok helyen már gazdaságos. A geotermikus energiaforrások is részesei lesznek minden jövőbeli energiaellátásnak. A geotermikus áramfejlesztés jó ideig jelentős volt a megújulók mezőnyében; 2011 óta azonban a napelemek már több áramot termelnek világszerte, mint a geotermia. Az EGS-rendszerekkel fel lehet- 
ne gyorsítani a geotermikus erőmüvek terjedését, de ehhez még jelentős kutatási/ fejlesztési erőfeszítések szükségesek.

A direkt hőhasználat fö komponense a földhőszivattyúkon alapszik; ez a technológia nemzetközileg terjed, jelenleg évi 20\%-os növekedéssel. A geotermikus távfütés további jövőbeli ígéretes technológia, amelyhez szükséges a visszasajtolás, főleg az üzemeltetés fenntarthatóságának biztosításához. Ha globálisan (egyelőre) nem is, lokálisan ígéretes lehet a mélygeotermia.

A magyar földtani adottságok majdnem hogy elkötelezően kedvezőek a geotermia hazai továbbfejlesztésére. Remélhetöleg a fejlödés egyöntetübb lesz, mint eddig, és hamarosan egyre több erőmü épül.

Ami a hosszú távú globális fejlődést illeti, elképzelhető, hogy főleg új, innovatív elvek/megoldások kerülhetnek kivitelezésre, például felhagyott olaj-/gázkutak csoportos kihasználása, gyorsabb és olcsóbb fúrástechnológia, csatolt $\mathrm{CO}_{2}$-besajtolás és hőkivétel, geotermikus tengervíz-sótalanítás, szuperkritikus fluidumtermelés (termelés a kritikus hőmérséklet felett), tengeri (offshore) erőmüvek.

Remélhetőleg Magyarország is szerepet kap egyik-másik ilyen „futurisztikus” fejlesztésben.

\section{IRODALOM}

Árpási M. (2005): Geothermal Update of Hungary 2000-2004. In: Proceedings World Geothermal Congress 2005, Antalya, Turkey, https://www.geothermal-energy.org/pdf/IGAstandard/ WGC/2005/0127.pdf

Bertani, R. (2015): Geothermal Power Generation in the World 2010-2014 Update Report. In: Proceedings World Geothermal Congress 2015, Melbourne, Australia, https://www.geothermal-energy.org/pdf/IGAstandard/WGC/2015/01001.pdf

Bobok E. - Tóth A. (2010): A geotermikus energia helyzete és perspektívái. Magyar Tudomány, 171, 8, 926-936. http://www.matud.iif.hu/2010/08/04.htm

EGEC (2019): 2018 EGREC Geothermal Market Report - Key Findings. https://www.egec.org/ media-publications/egec-geothermal-market-report-2018/

ETIP (2018): European Technology and Innovation Platform Deep Geothermal (ETIP-DG), 'Vi= sion for Deep Geothermal', Brussels, Belgium

GEA (2014): 2014 Annual U.S. \& Global Geothermal Power Production Report. Baltimore, USA: Geothermal Energy Association, http:/geo-energy.org/events/2014\%20annual\%20us\%20 $\& \% 20$ global\%20geothermal\%20power\%20production\%20report\%20final.pdf

Horváth F. - Musitz B. - Balázs A. et al. (2015): Evolution of the Pannonian Basin and Its Geothermal Resources. Geothermics, 53, 328-352. DOI: 10.1016/j.geothermics.2014.07.009, https:// www.researchgate.net/publication/264789043_Evolution_of_the_Pannonian_basin_and_its_ geothermal_resources

Lund, J. W - Boyd, T. L. (2015): Direct Utilization of Geothermal Energy 2015 Worldwide Review. Proceedings World Geothermal Congress 2015, Melbourne, Australia, https://www.unionegeotermica.it/pdfiles/usi-diretti-energia-geotermica-nel-mondo.pdf

Mádlné Szőnyi J. - Rybach L. - Lenkey L. et al. (2009): Fejlődési lehetőségek a geotermikus energia hasznosításában, különleges tekintettel a hazai adottságokra - Egy, az MTA számára 
készített tanulmány margójára... Magyar Tudomány, 170, 8, 989-1003. http://www.matud.iif. $\mathrm{hu} / 2009 / 09 \mathrm{aug} / 13 . \mathrm{htm}$

REN21 (2017): Renewables 2017 Global Status Report. Paris: REN21 Secretariat, https://www. ren21.net/wp-content/uploads/2019/05/GSR2017_Full-Report_English.pdf

Rybach L (2015): A geotermikus energia globális helyzete és kilátásai. Természet Világa Természettudományi Közlöny, 143, 3, 109-111. http://epa.oszk.hu/02900/02926/00027/pdf/ EPA02926_termeszet_vilaga_2015_03_109-111.pdf

Rybach L. - Sanner, B (2017): Geothermal Heat Pump Development Trends and Achievements in Europe. In: Bertani, R. (ed.): Perspectives for Geothermal Energy in Europe. London: Imperial College Press, 215-253.

ThinkGeoEnergy (2017): Think Geo Energy International Sites. www.thinkgeoenergy.com

Tóth A. (2010): Hungary Country Update 2005-2009. In: Proceedings World Geothermal Congress 2010, Bali, Indonesia, https://www.geothermal-energy.org/pdf/IGAstandard/WGC/2010/0125. pdf

Tóth A. (2015): Hungary Country Update 2010-2014. In: Proceedings World Geothermal Congress 2015, Melbourne, Australia, https://pangea.stanford.edu/ERE/db/WGC/papers/ WGC/2015/01024.pdf 